\title{
Lignans from Santalum album and Their Cytotoxic Activities
}

\author{
Yukiko Matsuo* and Yoshihiro Mimaki \\ Tokyo University of Pharmacy and Life Sciences, School of Pharmacy; 1432-1 Horinouchi, Hachiouji, Tokyo 192-0392, \\ Japan. Received December 24, 2009; accepted January 19, 2010; published online January 21, 2010
}

\begin{abstract}
A new neolignan, (7R,8R)-5-O-demethylbilagrewin (1), together with four known lignans (2-5), were isolated from the heartwood of Santalum album (Santalaceae). The structure of 1 was determined by analysis of extensive spectroscopic data. The isolated compounds and derivatives were evaluated for their cytotoxic activities against HL-60 human promyelocytic leukemia cells and A549 human lung adenocarcinoma cells. Compounds 1 and 2 exhibited cytotoxicity against HL-60 cells with $\mathrm{IC}_{50}$ values of $1.5 \pm 0.02$ and $4.3 \pm 0.13 \mu \mathrm{M}$, and against $\mathrm{A549}$ cells with $\mathrm{IC}_{50}$ values of $13.6 \pm 0.32$ and $19.9 \pm 1.27 \mu_{\mathrm{M}}$, respectively. The aldehyde group of 1 and 2 was revealed to be a structural requirement for the appearance of cytotoxicity in this type of lignans. These tumor cell deaths were shown to be mediated through induction of apoptosis.
\end{abstract}

Key words Santalum album; Santalaceae; neolignan; apoptosis; HL-60 cell; A549 cell

Santalum album (L.) (Santalaceae) is a tropical evergreen tree that grows in India, Indonesia, Malaysia, and Australia. Sandalwood oil, which is obtained by steam distillation from the heartwood of $S$. album, is widely used as an aromatherapy as an antidepressant, anti-inflammatory, antifungal, astringent, sedative, insecticide, and lung antiseptic. ${ }^{1)}$ Previous phytochemical studies on $S$. album have resulted in the isolation and identification of sesquiterpenes ${ }^{2-5}$ and aromatic compounds. ${ }^{6}$ In particular, $\alpha$-santalol and $\beta$-santalol with various biological activities ${ }^{7-9)}$ are known to be the main constituents of $S$. album. ${ }^{10)}$ The present investigation of the heartwood of $S$. album, with particular attention paid to its aromatic compounds, led to the isolation of five lignans (15), including one new neolignan, $(7 R, 8 R)-5$-O-demethylbilagrewin (1). This paper is a report on the structural determination of the new neolignan, and the cytotoxic activities of $\mathbf{1}$ 5 against HL-60 human promyelocytic leukemia cells and A549 human lung adenocarcinoma cells. The apoptosis induction properties of the lignans with the cytotoxic potency are also described.

The heartwood of $S$. album $(1.0 \mathrm{~kg})$ was extracted with hot $\mathrm{MeOH}$. The $\mathrm{MeOH}$ extract was passed through a porouspolymer polystyrene resin (Diaion HP-20) column, and the $\mathrm{MeOH}-\mathrm{eluted}$ fraction was subjected to column chromatography (CC) using silica gel and octadecylsilanized (ODS) silica gel, and to reversed-phase preparative HPLC, giving compounds $\mathbf{1}-\mathbf{5}$ (Fig. 1). Compounds $\mathbf{2}-\mathbf{5}$ were identified as bilagrewin (2), ${ }^{11)}$ dihydrodehydrodiconiferyl alcohol (3), ${ }^{12}$ $(-)$-syringaresinol (4), ${ }^{13)}$ and (-)-secoisolariciresinol (5), ${ }^{14)}$ respectively, by comparison of their physical and spectroscopic data with literature values.

Compound 1 was obtained as a pale yellow solid, $[\alpha]_{D}$ +2.4 in $\mathrm{CHCl}_{3}$, with a molecular formula of $\mathrm{C}_{20} \mathrm{H}_{20} \mathrm{O}_{8}$, which was assigned on the basis of the high-resolution (HR)electrospray ionization (ESI)-time of flight (TOF)-MS $(\mathrm{m} / \mathrm{z}$ $389.1224[\mathrm{M}+\mathrm{H}]^{+}$, Calcd 389.1236 ) and ${ }^{13} \mathrm{C}-\mathrm{NMR}$ (20 carbon signals) data. The IR spectrum of 1 suggested the presence of hydroxy $\left(3393 \mathrm{~cm}^{-1}\right)$ groups and a conjugated carbonyl group $\left(1663 \mathrm{~cm}^{-1}\right)$. The ${ }^{1} \mathrm{H}-\mathrm{NMR}$ spectrum showed signals for four aromatic protons at $\delta 7.39$ (d, $J=1.8 \mathrm{~Hz}, \mathrm{H}-$ 6), 7.20 (d, $J=1.8 \mathrm{~Hz}, \mathrm{H}-6^{\prime}$ ), 7.04 (d, $\left.J=1.8 \mathrm{~Hz}, \mathrm{H}-2\right)$, and $7.01\left(\mathrm{~d}, J=1.8 \mathrm{~Hz}, \mathrm{H}-2^{\prime}\right)$, two methoxy groups at $\delta 3.87(\mathrm{~s})$ and $3.79(\mathrm{~s})$, trans-olefinic protons at $\delta 7.52(\mathrm{~d}, J=15.8 \mathrm{~Hz}$,

$\left.\mathrm{H}-7^{\prime}\right)$ and $6.94\left(\mathrm{dd}, J=15.8,4.0 \mathrm{~Hz}, \mathrm{H}-8^{\prime}\right)$, and an aldehyde group at $\delta 9.82\left(\mathrm{~d}, J=4.0 \mathrm{~Hz}, \mathrm{H}-9^{\prime}\right)$. These ${ }^{1} \mathrm{H}-\mathrm{NMR}$ spectral data, together with analyses of the ${ }^{1} \mathrm{H}-{ }^{1} \mathrm{H}$ shift correlation spectroscopy (COSY) and ${ }^{1} \mathrm{H}$-detected heteronuclear multiple-quantum coherence (HMQC) spectra of 1 revealed that it contained two 1,3,4,5-tetrasubstituted aromatic rings and an $\alpha, \beta$-unsaturated propenal group as the partial structures of $\mathbf{1}$. In addition, a three-carbon sequence, $-\mathrm{O}-\mathrm{C}_{(7)} \mathrm{H}-\mathrm{C}_{(8)} \mathrm{H}(\mathrm{O})$ $\mathrm{C}_{(9)} \mathrm{H}_{2}-$, was deduced from the ${ }^{1} \mathrm{H}-\mathrm{NMR}$ signals at $\delta 5.47(\mathrm{~d}$, $J=7.9 \mathrm{~Hz}, \mathrm{H}-7$ ), 4.43 (ddd, $J=7.9,3.7,2.8 \mathrm{~Hz}, \mathrm{H}-8), 4.26$ (dd, $J=12.7,2.8 \mathrm{~Hz}, \mathrm{H}-9 \mathrm{a}$ ), and 3.99 (dd, $J=12.7,3.7 \mathrm{~Hz}, \mathrm{H}-$ 9b). In the ${ }^{1} \mathrm{H}$-detected heteronuclear multiple-bond connectivity (HMBC) spectrum of 1, long-range correlations were observed between $\mathrm{C}-7^{\prime}(\delta$ 153.3) and H-2' $(\delta$ 7.01)/H-6' $(\delta$ $7.20)$, C-7 $(\delta$ 77.2) and H-2 $(\delta 7.04) / \mathrm{H}-6(\delta 7.39)$, and between C-5' $(\delta$ 145.4) and H-7 ( $\delta$ 5.47). Furthermore, the proton signal arising from a methoxy group at $\delta 3.87(3 \mathrm{H}, \mathrm{s})$ showed an HMBC correlation with the C-3' carbon signal at $\delta 150.0$, whereas the proton signal due to another methoxy<smiles>COc1cc(C=CP)cc2c1O[C@H](CO)[C@@H](c1cc(O)c(O)c(O)c1)O2</smiles>
$1 \mathrm{R}=\mathrm{CHO}$ 1a $\mathrm{R}=\mathrm{CH}_{2} \mathrm{OH}$<smiles>COc1cc(C2Oc3c(OC)cc(CCCO)cc3[C@@H]2CO)ccc1O</smiles>
3<smiles>COc1cc(CC(CO)[C@H](CO)Cc2ccc(O)c(OC)c2)ccc1O</smiles>

Fig. 1. Chemical Structures of Compounds $\mathbf{1}-\mathbf{5}, \mathbf{1 a}$, and 2a from Santalum slbum 
Table $1 .{ }^{1} \mathrm{H}$ - and ${ }^{13} \mathrm{C}-\mathrm{NMR}$ Data for $\mathbf{1}$ and $\mathbf{1 a}$ in Pyridine- $d_{5}$ at $300 \mathrm{~K}$

\begin{tabular}{|c|c|c|c|c|c|c|}
\hline \multirow{2}{*}{ Position } & \multicolumn{3}{|c|}{1} & \multicolumn{3}{|c|}{$1 \mathrm{a}$} \\
\hline & ${ }^{1} \mathrm{H}$ & $J(\mathrm{~Hz})$ & ${ }^{13} \mathrm{C}$ & ${ }^{1} \mathrm{H}$ & $J(\mathrm{~Hz})$ & ${ }^{13} \mathrm{C}$ \\
\hline 1 & - & & 127.5 & - & & 128.1 \\
\hline 2 & $7.04 \mathrm{~d}$ & 1.8 & 103.6 & $7.01 \mathrm{~d}$ & 1.9 & 103.6 \\
\hline 3 & - & & 149.6 & - & & 149.4 \\
\hline 4 & - & & 136.7 & - & & 136.6 \\
\hline 5 & - & & 148.0 & - & & 148.0 \\
\hline 6 & $7.39 \mathrm{~d}$ & 1.8 & 110.1 & $7.38 \mathrm{~d}$ & 1.9 & 110.1 \\
\hline 7 & $5.47 \mathrm{~d}$ & 7.9 & 77.2 & $5.45 \mathrm{~d}$ & 7.8 & 77.3 \\
\hline 8 & 4.43 ddd & $7.9,3.7,2.8$ & 80.3 & 4.36 ddd & $7.8,3.5,3.0$ & 80.0 \\
\hline $9 a$ & $4.26 \mathrm{dd}$ & $12.7,2.8$ & 61.1 & $4.24 \mathrm{dd}$ & $12.6,3.0$ & 61.4 \\
\hline $\mathrm{b}$ & $3.99 \mathrm{dd}$ & $12.7,3.7$ & & $3.96 \mathrm{dd}$ & $12.6,3.5$ & \\
\hline $1^{\prime}$ & - & & 126.9 & - & & 129.6 \\
\hline $2^{\prime}$ & $7.01 \mathrm{~d}$ & 1.8 & 104.8 & $6.88 \mathrm{~d}$ & 1.6 & 103.2 \\
\hline $3^{\prime}$ & - & & 150.0 & - & & 150.0 \\
\hline $4^{\prime}$ & - & & 137.4 & - & & 134.0 \\
\hline $5^{\prime}$ & - & & 145.4 & - & & 145.4 \\
\hline $6^{\prime}$ & $7.20 \mathrm{~d}$ & 1.8 & 111.7 & $7.04 \mathrm{~d}$ & 1.6 & 108.6 \\
\hline $7^{\prime}$ & $7.52 \mathrm{~d}$ & 15.8 & 153.3 & $6.88 \mathrm{~d}$ & 15.7 & 129.9 \\
\hline $8^{\prime}$ & $6.94 \mathrm{dd}$ & $15.8,4.0$ & 127.5 & $6.63 \mathrm{dt}$ & $15.7,5.2$ & 130.3 \\
\hline $9^{\prime}$ & $9.82 \mathrm{~d}$ & 4.0 & 193.5 & $4.58 \mathrm{~d}$ & $5.2,1.3$ & 62.9 \\
\hline 3-OMe & $3.79 \mathrm{~s}$ & & 56.1 & $3.77 \mathrm{~s}$ & & 56.2 \\
\hline 3'-OMe & $3.87 \mathrm{~s}$ & & 56.0 & $3.83 \mathrm{~s}$ & & 55.9 \\
\hline
\end{tabular}

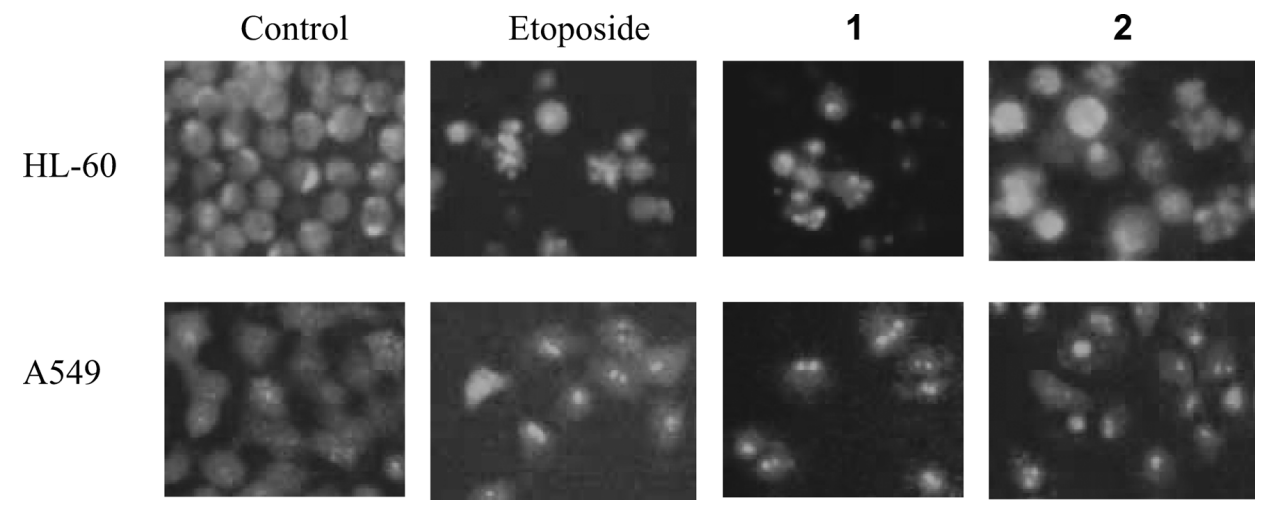

Fig. 2. Morphological Observations of Representative Fields of HL-60 and A549 Cells Stained with Acridine Orange to Evaluate Fragmented and Condensed Nuclear Chromatins after Treatment with 1, 2, or Etoposide

group at $\delta 3.79(3 \mathrm{H}, \mathrm{s})$ displayed a correlation with the $\mathrm{C}-3$ signal at $\delta$ 149.6. These spectroscopic data of 1 indicated that 1 was a neolignan whose planar structure was essentially analogous to that of $\mathbf{2}$ except for the lack of the methoxy group as observed at $\delta_{\mathrm{H}} 3.92\left(\mathrm{OCH}_{3}-5\right)$ and $\delta_{\mathrm{C}} 56.7\left(\mathrm{OCH}_{3}-\right.$ 5 ) in 2. The proton spin-coupling constant of ${ }^{3} J_{\mathrm{H}-7, \mathrm{H}-8}=$ $7.9 \mathrm{~Hz}$, together with the nuclear Overhauser effect (NOE) correlations between H-7 $(\delta$ 5.47) and H-9 $(\delta 4.26,3.99)$, and between H-8 $(\delta 4.43)$ and H-6 $(\delta 7.39)$ in the NOE correlation spectroscopy (NOESY) spectrum of $\mathbf{1}$, allowed the relative configuration of C-7 and C-8 to be assigned as transoriented. The Cotton effects observed in the circular dichroism (CD) spectrum of $\mathbf{1}[(\mathrm{MeOH}, \Delta \varepsilon): 224(+4.66), 236$ $(-3.02), 292(-0.35) \mathrm{nm}]$ were completely opposite to those of $2,{ }^{11)}$ and the absolute configurations at C-7 and C-8 of 1 were determined to be $7 R$ and $8 R$, respectively. Thus, this compound was represented by structure $\mathbf{1}$ and named (7R,8R)-5-O-demethylbilagrewin.

Compounds $\mathbf{1}-\mathbf{5}$ were evaluated for their cytotoxic activities against HL-60 cells and A549 cells. Neolignans 1 and $\mathbf{2}$ were cytotoxic to HL-60 cells with $\mathrm{IC}_{50}$ values of $1.5 \pm 0.02$ and $4.3 \pm 0.13 \mu \mathrm{M}$, and to A549 cells with $13.6 \pm 0.32$ and $19.9 \pm 1.27 \mu \mathrm{M}$, respectively. Etoposide, used as a positive control, had respective $\mathrm{IC}_{50}$ values of $0.48 \pm 0.03$ and $4.41 \pm$ $0.39 \mu \mathrm{m}$ against HL-60 cells and A549 cells. Compound 4 has been reported to show apoptosis-induced cytotoxicity against HL-60 cells with an $\mathrm{IC}_{50}$ value of $5.8 \pm 0.2 \mu \mathrm{M}^{15)}$; however, $\mathbf{4}$ as well as $\mathbf{3}$ and $\mathbf{5}$ did not show the cytotoxic activities against HL-60 cells or A549 cells at sample concentrations up to $23 \mu \mathrm{M}$ in our experiments (Table 2). As is evident from the microscopic photographs in Fig. 2, HL-60 and A549 cell deaths caused by $\mathbf{1}$ and $\mathbf{2}$ were shown to be partially mediated through the induction of apoptosis; nuclear chromatin condensation and cell shrinkage were characteristic features of the apoptosis-induced cells. HL-60 cells were more sensitive to $\mathbf{1}$ and $\mathbf{2}$ than A549 cells. Therefore, further studies were performed on the HL-60 cells. When apoptosis occurs, a typical apoptotic DNA ladder pattern can be observed in the agarose gel electrophoresis analysis of DNA. As shown in Fig. 3A, typical ladders of DNA fragmentation 
Table 2. Cytotoxic Activities of Compounds $\mathbf{1}-\mathbf{5}, \mathbf{1 a}, \mathbf{2 a}$, and Etoposide against HL-60 and A549 Cells

\begin{tabular}{ccc}
\hline \hline \multirow{2}{*}{ Compound } & \multicolumn{2}{c}{$\mathrm{IC}_{50}(\mu \mathrm{M})^{a)}$} \\
\cline { 2 - 3 } & $\mathrm{HL}-60$ & $\mathrm{~A} 549$ \\
\hline $\mathbf{1}$ & $1.5 \pm 0.02$ & $13.6 \pm 0.32$ \\
$\mathbf{1 a}$ & $>23.0$ & $>23.0$ \\
$\mathbf{2}$ & $4.3 \pm 0.13$ & $19.9 \pm 1.27$ \\
$\mathbf{2 a}$ & $>23.0$ & $>23.0$ \\
$\mathbf{3}$ & $>23.0$ & $>23.0$ \\
$\mathbf{4}$ & $>23.0$ & $>23.0$ \\
$\mathbf{5}$ & $>23.0$ & $>23.0$ \\
Etoposide & $0.48 \pm 0.03$ & $4.41 \pm 0.39$ \\
\hline
\end{tabular}

a) Data are presented as the mean value \pm S.E.M. of three experiments performed in triplicate.
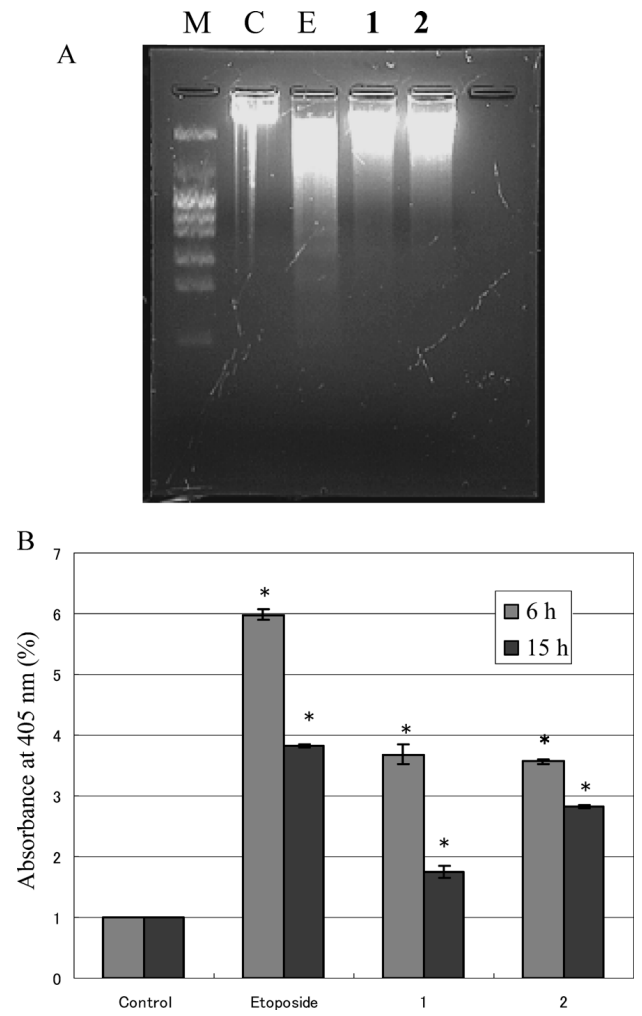

Fig. 3. (A) Induction of DNA Fragmentation by 1, 2, or Etoposide in HL60 Cells

HL-60 cells were incubated at $37^{\circ} \mathrm{C}$ for $18 \mathrm{~h}$ with $10 \mu \mathrm{g} / \mathrm{ml}$ of $\mathbf{1 , 2}$, or etoposide (E). DNA was then extracted and applied to agarose gel electrophoresis. M: DNA marker, C: control.

(B) Caspase-3 Activity in 1, 2, or Etoposide-Treated HL-60 Cell Lysates

$\mathrm{HL}-60$ cells were incubated at $37^{\circ} \mathrm{C}$ for 6 and $15 \mathrm{~h}$, respectively, with $10 \mu \mathrm{g} / \mathrm{ml}$ of $\mathbf{1}$, $\mathbf{2}$, or etoposide. Each value represents mean \pm S.E. from triplicate determinations. Caspase-3 activity was expressed as \% of control. The absorbances at $405 \mathrm{~nm}$ of the cleaved product by either 6 or $15 \mathrm{~h}$ in the control were 0.11 and 0.25 , respectively. $* p<0.05$, significantly different from the control group by the Student's $t$ test.

were detected when HL-60 cells were treated with $10 \mu \mathrm{g} / \mathrm{ml}$ of $\mathbf{1}$ and $\mathbf{2}$ for $18 \mathrm{~h}$. Compounds $\mathbf{1}$ and $\mathbf{2}$ were tested for their increasing activity of caspase-3, the common effector of most apoptotic pathways. Caspase-3 was markedly activated when HL-60 cells were treated with $\mathbf{1}$ and $\mathbf{2}$ at a sample concentration of $10 \mu \mathrm{g} / \mathrm{ml}$ for 6 and $15 \mathrm{~h}$, respectively (Fig. 3B). Our findings demonstrate that neolignans $\mathbf{1}$ and $\mathbf{2}$ significantly induced apoptotic death in HL-60 cells and A549 cells. Compounds $\mathbf{1}$ and $\mathbf{2}$ were treated with $\mathrm{NaBH}_{4}$ and
$\mathrm{CeCl}_{3}$ to give the corresponding C-9' allyl alcohol derivatives $^{16)}(\mathbf{1} \mathbf{a}, 2 \mathbf{2})$ (Fig. 1). Compounds 1a and 2a exhibited no apparent cytotoxic activities at a sample concentration of $23 \mu \mathrm{m}$ against both tumor cell lines, suggesting that the aldehyde group of $\mathbf{1}$ and $\mathbf{2}$ is a structural requirement for the appearance of cytotoxicity in this type of lignans.

\section{Experimental}

Optical rotations were obtained using a DIP-360 (Jasco, Tokyo, Japan) automatic digital polarimeter. IR spectra were recorded with a Jasco FT-IR 620 spectrophotometer. NMR spectra $\left(500 \mathrm{MHz}\right.$ for $\left.{ }^{1} \mathrm{H}-\mathrm{NMR}\right)$ were recorded with a DRX-500 spectrometer (Bruker, Karlsruhe, Germany), using standard Bruker pulse programs. Chemical shifts are given as $\delta$ values with reference to tetramethylsilane (TMS) as an internal standard. HR-ESI-TOF-MS data were obtained with an LCT mass spectrometer (Waters-Micromass, Manchester, U.K.). Diaion HP-20 (Mitsubishi-Chemical, Tokyo, Japan), BW-300 silica gel (Fuji-Silysia Chemical, Aichi, Japan), and ODS silica gel (Nacalai Tesque, Kyoto, Japan) were used for CC. TLC was carried out on precoated Silica gel $60 \mathrm{~F}_{254}\left(0.25 \mathrm{~mm}\right.$ thick, Merck, Darmstadt, Germany) and $\mathrm{RP}_{18}$ $\mathrm{F}_{254 \mathrm{~S}}$ plates $(0.25 \mathrm{~mm}$ thick, Merck), and the spots were visualized by spraying the plates with $10 \% \mathrm{H}_{2} \mathrm{SO}_{4}$ and then heating. HPLC was performed with a system composed of a CCPM pump (Tosoh, Tokyo, Japan), a CCP PX8010 controller (Tosoh), RI-8010 (Tosoh) and Shodex OR-2 (Showa-Denko, Tokyo, Japan) detectors, and a Rheodyne injection port. A TSK gel ODS$100 \mathrm{Z}$ column $(10 \mathrm{~mm}$ i.d. $\times 250 \mathrm{~mm}, 5 \mu \mathrm{m}$, Tosoh) was employed for preparative HPLC. The following materials and reagents were used for the cell cultures and the assay of cytotoxic activities: Spectra Classic microplate reader (Tecan, Salzburg, Austria); 96-well flat-bottom plate (Iwaki Glass, Chiba, Japan); JCRB 0085 HL-60 cells and JCRB 0076 A549 cells (Human Science Research Resources Bank, Osaka, Japan); fetal bovine serum (FBS) (Bio-Whittaker, Walkersville, MD, U.S.A.); $0.25 \%$ Trypsin-ethylene-diamine tetraacetic acid (EDTA) solution, RPMI 1640 medium, minimum essential medium (MEM), etoposide, and 3-(4,5-dimethylthiazol-2-yl)-2,5-diphenyl$2 H$-tetrazolium bromide (MTT) (Sigma, St. Louis, MO, U.S.A.); penicillin $\mathrm{G}$ and streptomycin sulfate (Gibco, Grand Island, NY, U.S.A.). All other chemicals used were of biochemical reagent grade.

Plant Material The heartwood of S. album was obtained from Uchida Wakannyaku, Tokyo, Japan. A small amount of the sample is preserved in our laboratory (06-004-SA).

Extraction and Isolation The heartwood of S. album (1.0 kg of dry weight) was extracted with hot $\mathrm{MeOH}$ (121). After removing the solvent, the $\mathrm{MeOH}$ extract $(91 \mathrm{~g})$ was passed through a Diaion HP-20 column and successively eluted with $30 \% \mathrm{MeOH}, 50 \% \mathrm{MeOH}, \mathrm{MeOH}$, EtOH, and EtOAc (each 91). $\mathrm{CC}$ of the $\mathrm{MeOH}$-eluted fraction $(40.0 \mathrm{~g})$ on silica gel eluted with a stepwise gradient mixture of hexane-EtOAc $(7: 1 ; 5: 1 ; 2: 1 ; 1: 1)$ and finally with $\mathrm{MeOH}$ alone, provided 13 fractions $(\mathrm{A}-\mathrm{M})$. Fraction $\mathrm{K}$ was chromatographed on ODS silica gel eluted with $\mathrm{MeCN}-\mathrm{H}_{2} \mathrm{O}(1: 2 ; 1: 1)$ and $\mathrm{MeOH}-\mathrm{H}_{2} \mathrm{O}(2: 1)$ to yield $\mathbf{1}(13.0 \mathrm{mg}), \mathbf{2}(7.7 \mathrm{mg}), \mathbf{3}(12.8 \mathrm{mg})$, and $\mathbf{5}$ $(5.0 \mathrm{mg})$. Fraction $\mathrm{J}$ was separated by an ODS silica gel column eluted with $\mathrm{MeCN}-\mathrm{H}_{2} \mathrm{O}(1: 2 ; 1: 1)$ and $\mathrm{MeOH}-\mathrm{H}_{2} \mathrm{O}(1: 1)$ to give $4(12.3 \mathrm{mg})$.

$(7 R, 8 R)$-5-O-demethylbilagrewin (1): Pale yellow solid, $[\alpha]_{\mathrm{D}}^{23}+2.4$ $(c=0.8, \mathrm{MeOH})$. IR $v_{\max }$ (film) $\mathrm{cm}^{-1}: 3393(\mathrm{OH}), 2936(\mathrm{CH})$, and 1663 $(\mathrm{C}=\mathrm{O})$. UV $\lambda_{\max }(\mathrm{MeOH}) \mathrm{nm}(\log \varepsilon): 225$ (3.36), 275 (2.66). CD $\lambda_{\max }$ $(\mathrm{MeOH}) \mathrm{nm}(\Delta \varepsilon): 224(+4.66), 236(-3.02), 292(-0.35) .{ }^{1} \mathrm{H}-$ and ${ }^{13} \mathrm{C}-$ NMR, see Table 1. HR-ESI-TOF-MS $m / z 389.1224[\mathrm{M}+\mathrm{H}]^{+}$(Calcd for $\mathrm{C}_{20} \mathrm{H}_{21} \mathrm{O}_{8}, 389.1236$ ).

Reduction of 1 and $2 \quad \mathrm{NaBH}_{4}(1.0 \mathrm{mg})$ and $\mathrm{CeCl}_{3} \cdot 7 \mathrm{H}_{2} \mathrm{O}(5.0 \mathrm{mg})$ were added to a solution of $1(5.0 \mathrm{mg})$ in $\mathrm{MeOH}(0.5 \mathrm{ml})$, and then the mixture was stirred at room temperature for $6 \mathrm{~h}$. After $0.1 \mathrm{M} \mathrm{HCl}(1.0 \mathrm{ml})$ was added to the reaction mixture, it was extracted with EtOAc $(3 \mathrm{ml} \times 3)$ and concentrated under reduced pressure. The crude product was purified by $\mathrm{CC}$ on silica gel using $\mathrm{MeCN}-\mathrm{H}_{2} \mathrm{O}(1: 1)$ to give $\mathbf{1 a}(4.8 \mathrm{mg})$. Using the same procedures, $2(5.0 \mathrm{mg})$ was reduced to $2 \mathrm{a}(0.6 \mathrm{mg})$, of which the physicochemical physical and spectral data were identical to those of nitidanin. ${ }^{17}$

Compound 1a: Pale yellow solid, $[\alpha]_{\mathrm{D}}^{25}-2.0(c=0.2, \mathrm{MeOH})$. IR $v_{\max }$ (film) $\mathrm{cm}^{-1}: 3430(\mathrm{OH}), 1641(\mathrm{C}=\mathrm{O})$. UV $\lambda_{\max }(\mathrm{MeOH}) \mathrm{nm}(\log \varepsilon): 227$ (3.84), 272 (3.44). CD $\lambda_{\max }(\mathrm{MeOH}) \mathrm{nm}(\Delta \varepsilon): 226(+5.17), 230(-8.41)$, $279(-3.12)$. ${ }^{1} \mathrm{H}-$ and ${ }^{13} \mathrm{C}-\mathrm{NMR}$, see Table 1. HR-ESI-TOF-MS $\mathrm{m} / \mathrm{z}$ $413.1205[\mathrm{M}+\mathrm{Na}]^{+}$(Calcd for $\mathrm{C}_{20} \mathrm{H}_{21} \mathrm{O}_{8}, 413.1212$ ).

HL-60 Cell Culture Assay HL-60 cells were maintained in an RPMI 1640 medium containing 10\% FBS supplemented with L-glutamine, $100 \mathrm{units} / \mathrm{ml}$ of penicillin $\mathrm{G}$, and $100 \mu \mathrm{g} / \mathrm{ml}$ of streptomycin sulfate. The leukemia cells were washed and re-suspended in this medium to $4 \times 10^{4}$ 
cells/ml, and $196 \mu \mathrm{l}$ of this cell suspension was placed in each well of a 96well flat-bottom plate. The cells were incubated in $5 \% \mathrm{CO}_{2} /$ air for $24 \mathrm{~h}$ at $37^{\circ} \mathrm{C}$. After incubation, $4 \mu \mathrm{l}$ of EtOH$-\mathrm{H}_{2} \mathrm{O}(1: 1)$ solution containing test compounds were added to give final concentrations of $0.1-20 \mu \mathrm{g} / \mathrm{ml} ; 4 \mu \mathrm{l}$ of EtOH- $\mathrm{H}_{2} \mathrm{O}(1: 1)$ was added into the control wells. The cells were further incubated for $72 \mathrm{~h}$ in the presence of each agent, and then the cell growth was evaluated by a modified MTT reduction assay. Briefly, after terminating the cell culture, $10 \mu 1$ of $5 \mathrm{mg} / \mathrm{ml}$ of MTT in PBS was added to every well, and the plate was reincubated in $5 \% \mathrm{CO}_{2}$ /air for $4 \mathrm{~h}$ at $37^{\circ} \mathrm{C}$. The plate was then centrifuged at $1500 \times \boldsymbol{g}$ for $5 \mathrm{~min}$ to precipitate the cells and MTT formazan. An aliquot of $150 \mu \mathrm{l}$ of the supernatant was removed from each well, and $175 \mu \mathrm{l}$ of dimethyl sulfoxide (DMSO) was added to dissolve the MTT formazan crystals. The plate was mixed on a microshaker for $10 \mathrm{~min}$, and then read on a microplate reader at $550 \mathrm{~nm}$.

A549 Cell Culture Assay A549 cells were maintained in MEM containing $10 \%$ FBS in a humidified $5 \% \mathrm{CO}_{2}$ atmosphere. Cells were trypsinized and re-suspended in this medium to $1 \times 10^{5}$ cells $/ \mathrm{ml}$, and $100 \mu \mathrm{l}$ of this cell suspension was placed in each well of a 96 -well flat-bottom plate. The cells were incubated in $5 \% \mathrm{CO}_{2} /$ air for $24 \mathrm{~h}$ at $37^{\circ} \mathrm{C}$. After washing once with phosphate buffered saline (PBS), they were treated for $72 \mathrm{~h}$ in the presence of $196 \mu \mathrm{l}$ of fresh medium with $4 \mu \mathrm{l}$ of test compounds. Then the cell growth was evaluated by a modified MTT reduction assay. The plate was reincubated in $5 \% \mathrm{CO}_{2} /$ air for $4 \mathrm{~h}$ at $37^{\circ} \mathrm{C}$ with MTT $0.2 \mathrm{mg} / \mathrm{ml}$ in MEM supplemented with $10 \%$ FBS. After the medium was removed, the MTT formazan crystals were dissolved with $100 \mu$ of DMSO. The plate was mixed on a microshaker for $10 \mathrm{~min}$ and then read on a microplate reader at $550 \mathrm{~nm}$.

Assay for Detection of DNA Fragmentation The cells were incubated at $37^{\circ} \mathrm{C}$ for $18 \mathrm{~h}$. DNA was extracted with a commercially available kit (Wizard Genomic DNA Purification Kit, Promega, WI, U.S.A.). In brief, cells $\left(1.2 \times 10^{6}\right.$ cells $)$ were centrifuged for $5 \mathrm{~min}$ at $10000 \boldsymbol{g}$. The cell plate was resuspended in $600 \mu \mathrm{l}$ of a nuclei lysis solution. Then, $3 \mu \mathrm{l} \mathrm{of} 4 \mathrm{mg} / \mathrm{ml}$ RNaseA solution was added to the cell lysate, and the solution was incubated at $37^{\circ} \mathrm{C}$ for $15 \mathrm{~min}$. Protein precipitation solution $(200 \mu \mathrm{l})$ was added to the RNaseA-treated cell lysate, and the mixture was incubated for $5 \mathrm{~min}$ on ice and centrifuged at $10000 \boldsymbol{g}$ for $5 \mathrm{~min}$. The supernatant was transferred to a clean $1.5 \mathrm{ml}$ microcentrifuged tube containing $600 \mu \mathrm{l}$ of 2-propanol and mixed by inversion. After centrifugation at $10000 \boldsymbol{g}$ for $5 \mathrm{~min}$, DNA was visible as a small white pellet, and it was washed with $70 \% \mathrm{EtOH}$. Finally, the pellet was resuspended in $25 \mu \mathrm{l}$ of DNA rehydration solution and incubated at $65^{\circ} \mathrm{C}$ for $1 \mathrm{~h}$, which was stored at $-20^{\circ} \mathrm{C}$ until use. The sample $(10$ $15 \mu \mathrm{l}$ ) was applied to $2 \%$ agarose gel electrophoresis in a $40 \mathrm{~mm}$ Tris-acetate buffer $(\mathrm{pH} 7.4)$ at $50 \mathrm{~V}$ for $1 \mathrm{~h}$. DNA molecular weight marker ( $\mathrm{pH}$ marker, Takara, Shiga, Japan) and DNA from apoptotic HL-60 cells induced by $10 \mu \mathrm{g} / \mathrm{ml}$ etoposide were used for calibration. The DNA fragmentation pattern was examined in photographs taken under UV illumination.

Assay for Caspase-3 Activation The activity of caspase-3 was measured using a commercially available kit (APPOCYTO Caspase-3 Colorimetric Assay Kit, MBL, Aichi, Japan). HL-60 cells $\left(2 \times 10^{6}\right)$ were treated with test samples for 6 and $15 \mathrm{~h}$, respectively, and the cells were centrifuged and collected. Cell pellets were suspended in $60 \mu \mathrm{l}$ of an ice cold cell lysis buffer and incubated on ice for $10 \mathrm{~min}$. This cell pellet suspension was centrifuged at $10000 \mathrm{~g}$ for $5 \mathrm{~min}$, and the supernatant was collected. The cell lysate ( $50 \mu \mathrm{l}$, equivalent to $200 \mu \mathrm{g}$ of protein) was mixed with $50 \mu \mathrm{l}$ of $2 \times$ reaction buffer containing the substrates for caspase-3 (DEVD- $p$ NA ( $p$-nitroanilide)). After incubation for $2 \mathrm{~h}$ at $37^{\circ} \mathrm{C}$, the absorbance at $405 \mathrm{~nm}$ of the liberated chromophore $p$ NA was measured using a microplate reader. The activity of caspase-3 was evaluated in triplicate.

Acknowledgments We are grateful to Dr. Y. Shida and Mr. H. Fukaya, Tokyo University of Pharmacy and Life Sciences, for the mass spectra and elemental analyses.

\section{References}

1) George A. B., Ioana G. C., Food Chem. Toxicol., 46, 421- 432 (2008).

2) Ochi T., Shibata H., Higuti T., Kodama K., Kusumi T., Takaishi Y., J. Nat. Prod., 68, 819-824 (2005).

3) Christenson P. A., Secord N., Willis B. J., Phytochemistry, 20, 11391141 (1981).

4) Kim T. H., Ito H., Hatano T., Hasegawa T., Akiba A., Machiguchi T., Yoshida T., J. Nat. Prod., 68, 1805-1808 (2005).

5) Kim T. H., Ito H., Hatano T., Takayasu J., Tokuda H., Nishino H., Machiguchi T., Yoshida T., Tetrahedron, 62, 6981-6989 (2006).

6) Kim T. H., Ito H., Hayashi K., Hasegawa T., Machiguchi T., Yoshida T., Chem. Pharm. Bull., 53, 641-644 (2005).

7) Dwivedi C., Valluri H. B., Guan X., Agarwal R., Carcinogenesis, 27, 1917-1922 (2006).

8) Kaur M., Agarwal C., Singh R. P., Guan X., Dwivedi C., Agarwal R., Carcinogenesis, 26, 369-380 (2005).

9) Ohmori A., Shinoyama K., Utsu Y., Tokunaga S., Hasegawa Y., Kamei C., Jpn. J. Neuropsychoph., 27, 167-171 (2007).

10) Howes M.-J. R., Simmonds M. S. J., J. Chromatogr. A, 1028, $307-$ 312 (2004).

11) Chen J. J., Wang T. Y., Hwang T. L., J. Nat. Prod., 71, 212-217 (2008).

12) Fukuyama Y., Nakahara M., Minami H., Kodama M., Chem. Pharm. Bull., 44, 1418-1420 (1996).

13) Zhuang L.-G., Seligmann O., Jurcic K., Wagner H., Planta Med., 45, $172-176$ (1982).

14) Veselova M. V., Fedoreev S. A., Vasilevskaya N. A., Denisenko V. A., Gerasimenko A. V., Pharm. Chem. J., 41, 88-93 (2007).

15) Park B.-Y., Oh S.-R., Ahn K.-S., Kwon O.-K., Lee H.-K., Int. Immunopharmacol., 8, 967-973 (2008).

16) Fukuyama Y., Hasegawa T., Toda M., Kodama M., Okazaki H., Chem. Pharm. Bull., 40, 252-254 (1992).

17) Ishikawa T., Seki M., Nishigaya K., Miura Y., Seki H., Chen I.-S., Ishii H., Chem. Pharm. Bull., 43, 2014-2018 (1995). 